\title{
Hubungan Kadar FT4 dan TSH Serum dengan Profil Lipid Darah pada Pasien Hipertiroid yang Dirawat Inap di RSUP Dr. M. Djamil Padang Tahun 2009 - 2013
}

\author{
Aga Pratama ${ }^{1}$, Eti Yerizel $^{2}$, Rudy Afriant $^{3}$
}

\begin{abstract}
Abstrak
Hipertiroid merupakan sindroma klinis yang terjadi bila jaringan terpajan dengan jumlah hormon tiroid yang berlebihan karena hiperaktivitas kelenjar tiroid. Hal tersebut akan memberikan efek spesifik terhadap metabolisme sel, termasuk metabolisme lipid. Perubahan metabolisme lipid pada hipertiroid akan menimbulkan manifestasi klinis seperti gangguan mood, peningkatan perilaku depresi, dan peningkatan perilaku agresif. Dalam diagnosis pasien hipertiroid, pemeriksaan kadar FT4 dan TSH serum menjadi tes fungsi tiroid yang tepat. Penelitian ini bertujuan untuk melihat bagaimana hubungan antara kadar FT4 dan TSH serum dengan profil lipid darah pada pasien hipertiroid. Penelitian ini menggunakan data deskriptif di Instalasi Rekam Medis RSUP dr. M. Djamil Padang pada bulan Februari 2013 sampai Juli 2013. Data yang dikumpulkan berasal dari catatan rekam medik pasien hipertiroid yang dirawat inap berjumlah 21 orang dengan teknik total sampling. Analisis bivariat digunakan untuk melihat hubungan antara kadar FT4 dan TSH serum dengan profil lipid darah. Dari sampel yang ada diperoleh data rerata profil lipid, yakni: 143,33 mg/dl (kolesterol darah total); 42,06 mg/dl (HDL); 85,45 mg/dl (LDL); dan 77,19 mg/dl (trigliserida). Berdasarkan uji korelasi regresi, terdapat korelasi negatif antara kadar FT4 dengan kadar kolesterol darah total, HDL, dan LDL, tetapi tidak terdapat korelasi antara kadar FT4 dengan trigliserida. Hubungan antara kadar TSH serum dengan kolesterol darah total dan LDL mempunyai korelasi positif, tetapi tidak terdapat korelasi antara kadar TSH serum dengan HDL dan trigliserida. Penelitian ini memperlihatkan bahwa sebagian besar profil lipid darah mempunyai korelasi dengan kadar FT4 dan TSH serum, kecuali trigliserida.
\end{abstract}

Kata kunci: kadar FT4 dan TSH serum, profil lipid darah, hipertiroid

\begin{abstract}
Hyperthyroidism is a clinical syndrome that occurs when tissues are exposed by excessive amount of thyroid hormones due to thyroid gland hiperactivity. It has spesific effects on cell metabolism, including lipid metabolism. $L$ ipid metabolism disorder in hyperthyroid will inflict clinical manifestation; such as mood disorders, depression, and increased aggressive behavior. In diagnose patient with hyperthyrodism, FT4 and TSH serum level test are the appropriate thyroid function test. The objective of this study was to determine relationship between FT4 and TSH serum level with blood lipid profile in patient with hyperthyrodism. This studies got the descriptive data in Medical Records Departement of RSUP dr. M. Djamil Padang from February 2013 to July 2013. Data of 21 hyperthyrodism patient were got with total sampling technique. Bivariat analysis is used to examine the relationship between FT4 and TSH serum level with blood lipid profile. From the sampel was obtained data of profile lipid average, that is 143,33 $\mathrm{mg} / \mathrm{dl}$ (total cholesterol); 42,06 $\mathrm{mg} / \mathrm{dl}$ (HDL); 85,45 mg/dl (LDL); dan 77,19 mg/dl (triglycerides). Based on the regression test, there was negative correlation between FT4 level with total cholesterol, HDL, and LDL, but, there wasn't correlation between FT4 level with triglycerides. The relationship between TSH serum level with total cholesterol and LDL had positive correlation. But, there isn't evidence of correlation between TSH serum level with HDL and triglycerides. This study shows that the most of blood lipid profile has correlation with FT4 and TSH serum level, except triglycerides.
\end{abstract}

Keywords: FT4 and TSH serum level, blood lipid profile, hyperthyrodism

Affiliasi penulis: ${ }^{1}$ Fakultas Kedokteran Unand, ${ }^{2}$ Bagian Biokimia FK Unand, ${ }^{3}$ Bagian IImu Penyakit Dalam FK Unand Korespondensi: Aga Pratama, Email : agapratama80@gmail.com, Telp: 085274192871

\section{PENDAHULUAN}

Hormon tiroid menjadi salah satu hormon yang dibutuhkan oleh hampir seluruh proses tubuh termasuk metabolisme, sehingga keadaan hipo/ hipertiroid berpengaruh pada berbagai peristiwa dijaringan tubuh manusia. Hipotiroid dianggap sebagai keadaan di mana efek hormon tiroid di jaringan tubuh menurun, sedangkan hipertiroid adalah kelebihan hormon tiroid yang beredar dalam sirkulasi akibat kelenjar tiroid yang hiperaktif (hiperfungsi). ${ }^{1-4}$

American Association of Clinical Endokrinologis memperkirakan terdapat 27 juta orang Amerika menderita hipertiroid/hipotiroid, dimana lebih dari setengah penderita tidak terdiagnosis. Di Indonesia, kejadian hipertiroid berkisar antara 44\% - 48\% dari seluruh kelainan kelenjar tiroid yang ditemui dan diperkirakan terdapat 12 juta kasus hipertiroid pada tahun 1960. Data tersebut memperlihatkan jumlah kasus hipertiroid yang cukup tinggi terjadi pada populasi negara maju maupun negara berkembang. 
Distribusi menurut jenis kelamin dan umur pada penyakit hipertiroid amat bervariasi, hipertiroid lebih sering terjadi pada wanita dibandingkan pria dengan perbandingan 5:1. Data beberapa rumah sakit di Indonesia juga memperlihatkan hal yang hampir sama. Kasus di RSUP Palembang adalah 3,1:1, di RSCM Jakarta 6:1, di RS Dr. Sutomo 8:1, dan di RSHS Bandung 10:1. Pasien hipertiroid umumnya berusia antara 20-40 tahun, sedangkan kasus hipertiroid di RSUP dr. M. Djamil Padang terbanyak ditemukan pada usia 30-40 tahun. .,8 $^{2}$

Hormon tiroid yang dihasilkan oleh kelenjar tiroid mempunyai efek spesifik terhadap berbagai metabolisme sel, termasuk metabolisme lipid. Kondisi peningkatan kadar hormon tiroid dan penurunan kadar TSH serum pada penderita hipertiroid akan meningkatkan biosintesis kolesterol sel, sekresi kolesterol oleh hati, proses konversi HDL menjadi VLDL di hati, aktivitas enzim LPL di membran sel, dan meningkatkan modulasi aktivitas reseptor LDL sel tubuh. Perubahan proses metabolisme lipid tersebut mengakibatkan terjadinya perubahan profil lipid darah, yakni berupa penurunan nilai profil lipid darah pada penderita hipertiroid. Penelitian ahli di Nepal juga memperlihatkan hubungan yang jelas antara profil lipid darah dengan kadar FT4 dan TSH serum pada hipertiroid. Terjadi perubahan profil lipid darah pada penderita hipertiroid dengan nilai rerata kolesterol $143,12 \mathrm{mg} / \mathrm{dl}$ dan rerata trigliserida $87,32 \mathrm{mg} / \mathrm{dl}$, serta perubahan nilai FT4 dan TSH serum dengan rerata FT4 2,66 pg/ml dan TSH serum 0,32 mU/L. ${ }^{1-3,9-11}$

Kadar kolesterol darah penderita hipertiroid yang rendah dari nilai normal tersebut dapat menimbulkan bahaya yang mungkin tidak disadari. Pada titik penurunan kadar kolesterol tertentu akan menyebabkan gangguan proses fisiologis sel neuron otak yang berdampak timbulnya gangguan kesehatan mental karena terjadinya penurunan kadar serotonin sebagai neurotransmiter pengaturan pusat suasana hati di otak. Peneliti dari Universitas San Diego California melalui sebuah studi yang dilakukan menyatakan adanya kecenderungan peningkatan perilaku kekerasan pada seseorang dengan hipokolesterolemia. Selain itu, peneliti dari Institut Max Plank Psikiatri menyatakan ada korelasi antara kadar kolesterol darah yang rendah dengan resiko bunuh diri, gangguan mood, perilaku depresi, dan perilaku agresif. Beberapa penelitian lain juga menyebutkan timbulnya gangguan sistem kekebalan tubuh, gangguan penyerapan vitamin, dan potensi timbulnya kanker pada kondisi hipokolesterolemia. ${ }^{12,13}$

Dalam diagnosis klinis hipertiroid, tes fungsi tiroid berupa pengukuran kadar hormon tiroid darah biasa digunakan. Pemeriksaan kadar FT4 dan TSH serum menjadi pemeriksaan standar yang banyak dipakai oleh dokter. Hal ini disebabkan karena pemeriksaan FT4 secara umum tidak terpengaruh oleh perubahan konsentrasi protein pengikat (TBG) di dalam plasma dan FT4 menjadi fraksi aktif hormon tiroid di dalam tubuh. Selain itu, pemeriksaan TSH serum juga dipercaya dapat memprediksi fungsi tiroid berdasarkan prinsip umum umpan balik negatif dan juga tidak terpengaruh oleh perubahan konsentrasi protein pengikat (TBG) di dalam plasma. Berbeda dengan sifat T3 dan T4 yang terikat dengan protein TBG di dalam plasma, sehingga dengan terjadinya lonjakan konsentrasi TBG (seperti dalam kehamilan) atau penurunan konsentrasi TBG (seperti pada pasien gangguan fungsi hati) akan juga mempengaruhi kadar T3 dan T4 darah. Berdasarkan hal tersebut, pemeriksaan FT4 dan TSH serum dianggap sebagai metode diagnosis klinis yang tepat pada kasus hipertiroid. ${ }^{9,14}$

Dengan diketahuinya hubungan hormon tiroid dengan metabolisme lipid, adanya efek perubahan kadar lipid dalam darah pada penderita hipertiroid seperti efek negatif penurunan kadar kolesterol diatas, serta belum adanya penelitian yang menghubungkan kadar FT4 dan TSH serum dengan profil lipid darah pada pasien hipertiroid yang dirawat inap di RSUP DR. M. Djamil Padang, oleh karena itu dilakukanlah penelitian tentang hubungan kadar FT4 dan TSH serum dengan profil lipid darah pada pasien hipertiroid yang dirawat inap di RSUP dr. M. Djamil Padang.

\section{METODE}

Penelitian ini dilakukan di Instalasi Rekam Medis RSUP dr. M. Djamil Padang dari bulan Februari 2013 sampai Juli 2013. Subjek dalam penelitian ini sebanyak 21 orang yang merupakan pasien hipertiroid yang memenuhi kriteria inklusi dan tidak memiliki kriteria eksklusi. Pemilihan subjek dilakukan secara total sampling. Instrumen yang digunakan dalam penelitian adalah data rekam medik pasien hipertiroid yang dirawat inap di RSUP dr. M. Djamil Padang. Data yang diperoleh diolah dengan menggunakan sistem komputerisasi kemudian dianalisis dengan uji korelasi regresi.

\section{HASIL}

Adapun karakteristik pasien hipertiroid tersebut dapat dilihat pada Tabel 1.

Tabel 1. Karakteristik umur pasien hipertiroid

\begin{tabular}{ccc}
\hline \multirow{2}{*}{ Karakteristik } & \multicolumn{2}{c}{ Pasien Hipertiroid } \\
\cline { 2 - 3 } & $\begin{array}{c}\text { Jumlah } \\
\text { (orang) }\end{array}$ & $\begin{array}{c}\text { Persentase } \\
(\%)\end{array}$ \\
\hline Kelompok Umur (Tahun) & & \\
$15-24$ & 2 & 9,5 \\
$25-34$ & 3 & 14,3 \\
$35-44$ & 7 & 33,3 \\
$45-54$ & 5 & 23,8 \\
$55-64$ & 3 & 14,3 \\
$65-74$ & 1 & 4,8 \\
$\geq 75$ & - & - \\
\hline Total & 21 & 100 \\
\hline Jenis Kelamin & & \\
Laki-laki & 6 & 28,6 \\
Perempuan & 15 & 71,4 \\
\hline Total & 21 & 100 \\
\hline
\end{tabular}

Tabel 1. menunjukkan kelompok umur tertinggi pada pasien hipertiroid tersebut adalah 35 44 tahun (33,3\%). Menurut jenis kelamin, pasien sebagian besar adalah perempuan $(71,4 \%)$. 
Tabel 2. Rerata kadar FT4 pasien hipertiroid

\begin{tabular}{cccc}
\hline & $\begin{array}{c}\text { Kadar FT4 } \\
(\mathrm{pmol} / \mathrm{L})\end{array}$ & $\begin{array}{c}\text { Kadar TSH } \\
(\mu \mathrm{IU} / \mathrm{mL})\end{array}$ & \\
& & & \\
& & & \\
& & & \\
\hline $\begin{array}{c}\text { Rerata } \pm \text { SD } \\
\mathbf{n}\end{array}$ & $\begin{array}{c}81,69 \pm 76,99 \\
21\end{array}$ & $0,24 \pm 0,70$ \\
& & & \\
& & \\
\end{tabular}

Tabel 2. menunjukkan rerata kadar FT4 pasien hipertiroid adalah $81,69 \pm 76,99 \mathrm{pmol} / \mathrm{L}$ dan rerata TSH serumnya $0,24 \pm 0,70 \mu \mathrm{lU} / \mathrm{ml}$.

Tabel 3. Rerata profil lipid darah pasien hipertiroid

\begin{tabular}{cccccc} 
& $\begin{array}{c}\mathrm{TC} \\
(\mathbf{m g} / \mathbf{d l})\end{array}$ & $\begin{array}{c}\mathrm{HDL} \\
(\mathbf{m g} / \mathbf{d l})\end{array}$ & $\begin{array}{c}\mathrm{LDL} \\
(\mathbf{m g} / \mathbf{d l})\end{array}$ & $\begin{array}{c}\mathrm{TG} \\
(\mathbf{m g} / \mathbf{d l})\end{array}$ & Ket \\
\hline Rerata \pm & $143,3 \pm$ & $42,06 \pm$ & $85,45 \pm$ & $77,19 \pm$ \\
SD & 49,82 & 16,42 & 36,08 & 31,20 & \\
$\mathbf{n}$ & 21 & 21 & 21 & 21 &
\end{tabular}

Tabel 3. menunjukkan rerata profil lipid darah pasien hipertiroid adalah 143,3 \pm 49,82 $\mathrm{mg} / \mathrm{dl}$ (kolesterol darah total); 42,06 $\pm 16,42 \mathrm{mg} / \mathrm{dl}$ (HDL); $85,45 \pm 36,08 \mathrm{mg} / \mathrm{dl}$ (LDL); dan 77,19 $\pm 31,20 \mathrm{mg} / \mathrm{dl}$ (trigliserida).

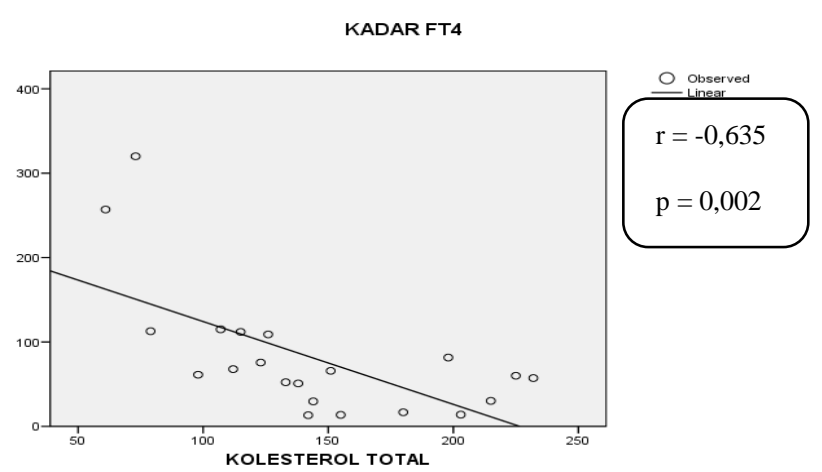

Gambar 1. Korelasi negatif antara kadar FT4 dengan kadar kolesterol darah total

Pada gambar 1, terlihat korelasi negatif antara kadar FT4 dengan kadar kolesterol darah total pada pasien hipertiroid dengan harga $r=-0,635 \quad(-1-0,43)$. Dimana semakin tinggi kadar FT4, maka semakin rendah kadar kolesterol darah total. ${ }^{15,16}$

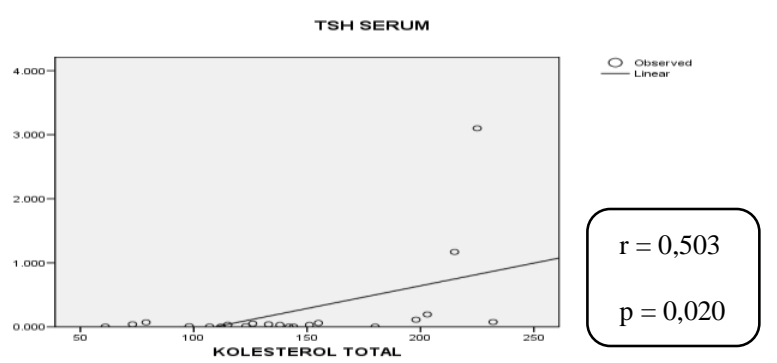

Gambar 2. Korelasi positif antara kadar TSH serum dengan kadar kolesterol darah total

Pada gambar 2, terlihat korelasi positif antara kadar TSH serum dengan kadar kolesterol darah total pada pasien hipertiroid dengan harga $r=0,503(0,43-1)$. Dimana semakin rendah kadar TSH serum, maka semakin rendah pula kadar kolesterol darah total. ${ }^{15,16}$

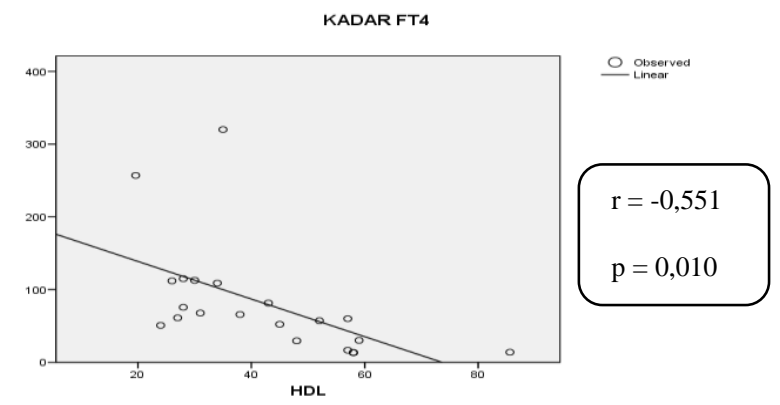

Gambar 3. Korelasi negatif antara kadar FT4 dengan kadar HDL

Pada gambar 3 , terlihat korelasi negatif antara kadar FT4 dengan kadar HDL pada pasien hipertiroid dengan harga $r=-0,551(-1--0,43)$. Dimana semakin tinggi kadar FT4, maka semakin rendah kadar

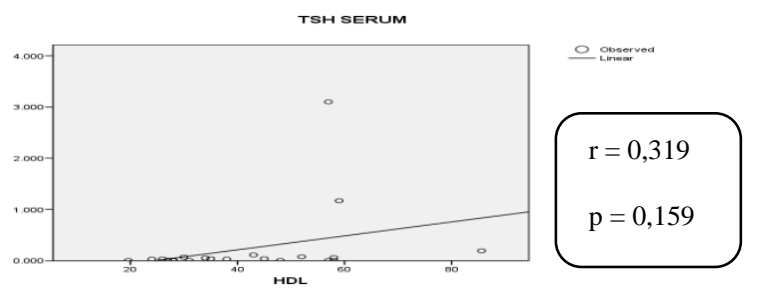

Gambar 4. korelasi antara kadar TSH serum dengan kadar HDL

Pada gambar 4, tidak terlihat korelasi antara kadar TSH serum dengan kadar HDL pada pasien hipertiroid dengan harga $r=0,319(<0,43-1)$. Namun grafik yang menunjukkan arah korelasi positif berarti semakin rendah kadar TSH serum, maka semakin rendah pula kadar HDL. ${ }^{15,16}$ 


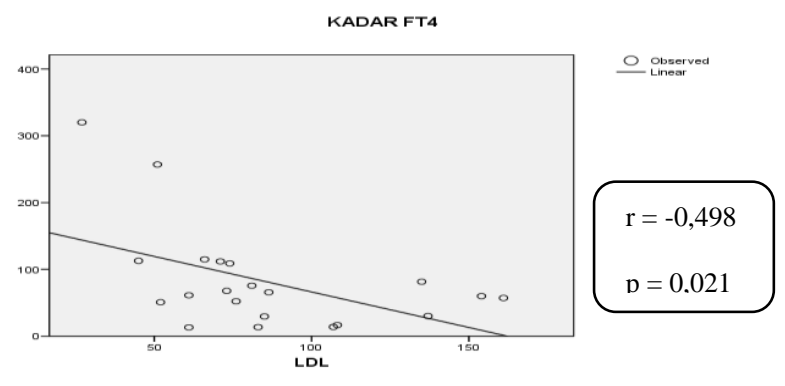

Gambar 5. Korelasi negatif antara kadar FT4 dengan kadar LDL

Pada gambar 5, terlihat korelasi negatif antara kadar FT4 dengan kadar LDL pada pasien hipertiroid dengan harga $r=-0,498 \quad(-1--0,43)$. Dimana semakin semakin tinggi kadar FT4, maka semakin rendah kadar LDL. 16,

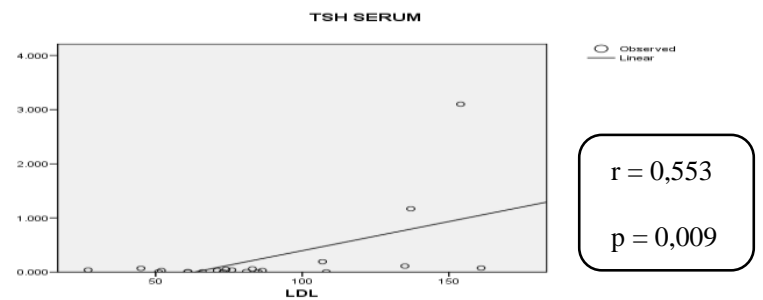

Gambar 6. Korelasi positif antara kadar TSH serum dengan kadar LDL

Pada gambar 6 , terlihat korelasi positif antara kadar TSH serum dengan kadar LDL pada pasien hipertiroid dengan harga $r=0,553(0,43-1)$. Dimana semakin rendah kadar TSH serum, maka semakin rendah kadar LDL. ${ }^{15,16}$

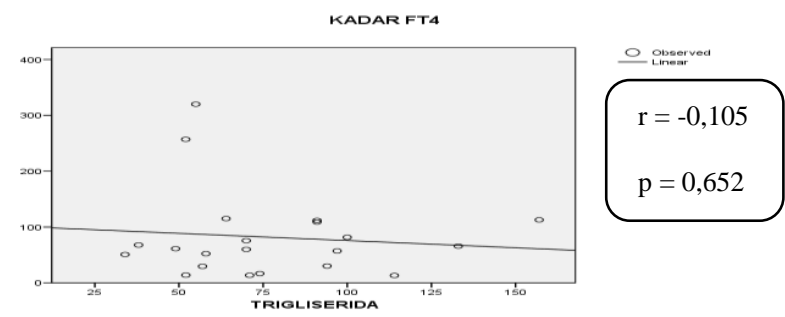

Gambar 7. Korelasi antara kadar FT4 dengan kadar Trigliserida

Pada gambar 7, tidak terlihat korelasi antara kadar FT4 dengan kadar Trigliserida pada pasien hipertiroid dengan harga $r=-0,105(>-1--0,43)$. Namun grafik yang menunjukkan arah korelasi negatif berarti semakin tinggi kadar FT4, maka semakin rendah kadar Trigliserida. ${ }^{15,16}$

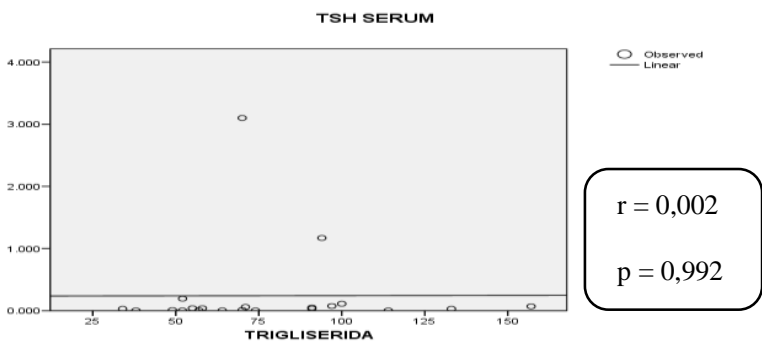

Gambar 8. Korelasi antara kadar TSH serum dengan kadar Trigliserida

Pada gambar 8, tidak terlihat korelasi antara kadar TSH serum dengan kadar Trigliserida pada pasien hipertiroid dengan harga $r=0,002(<0,43-1)$. Namun grafik yang menunjukkan arah korelasi positif berarti semakin rendah kadar TSH serum, maka semakin rendah kadar Trigliserida. ${ }^{15,16}$

\section{PEMBAHASAN}

Kelompok umur tertinggi pasien hipertiroid adalah 35-45 tahun (33,33\%). Hal ini disebabkan karena adanya kecenderungan kasus hipertiroid muncul pada usia dimana masa stres yang ekstrim dan selama masa reproduktif wanita, yakni golongan usia dewasa. Data penelitian yang diperoleh juga sejalan dengan hasil penelitian yang pernah dilakukan di RSUP dr. M. Djamil Padang sebelumnya, dengan kasus terbanyak ditemukan pada usia 30-40 tahun. ${ }^{1,4,7,8,17}$

Menurut jenis kelamin, sebagian besar pasien adalah perempuan $(71,4 \%)$. Banyaknya pasien hipertiroid yang berjenis kelamin perempuan diduga karena adanya pengaruh hormon estrogen yang bersifat dominan pada perempuan. Dimana hormon estrogen sendiri dianggap sebagai salah satu faktor pendorong timbulnya reaksi autoimun yang dikenal sebagai penyebab (causa) hipertiroid. Data penelitian yang diperoleh juga sesuai dengan hasil penelitian kasus hipertiroid di berbagai rumah sakit, yang menempatkan perempuan sebagai penderita hipertiroid terbanyak di Indonesia. .,7,8 $^{6}$

Rerata kadar FT4 yang diperoleh adalah $81,69 \pm 76,99 \mathrm{pmol} / \mathrm{L}$ dan rerata TSH serum $0,24 \pm$ $0,70 \mu \mathrm{IU} / \mathrm{ml}$. Hal ini memperlihatkan bahwa rerata FT4 dan TSH serum pasien hipertiroid mengalami perubahan dari nilai normal (FT4 me $\uparrow$ dan TSH me $\downarrow$ ), yakni 12-22 pmol/L (FT4) dan 0,27- 4,2 $\mu \mathrm{lU} / \mathrm{mL}$ (TSH serum). Perubahan nilai hormon tiroid dari nilai normal pada pasien hipertiroid terjadi karena adanya peningkatan kecepatan pertumbuhan kelenjar tiroid dan produksi hormon tiroid.Kondisi ini membuat kelenjar tiroid menjadi lebih aktif dalam hal memproduksi hormon tiroid. Sehingga, terjadilah peningkatan kadar hormon tiroid yang beredar di sirkulasi, termasuk kadar FT4. Peningkatan kadar hormon tiroid di sirkulasi akan menekan produksi TSH 
di hipofisis dengan mekanisme umpan balik negatif agar fungsi TSH sebagai salah satu pencetus produksi hormon tiroid dapat dibatasi fungsinya dan meminimalisir lonjakan kadar hormon tiroid yang terjadi. Hal inilah yang menyebabkan terjadinya penurunan kadar TSH serum pada pasien hipertiroid. $^{1,8,9,14,18}$

Rerata kadar kolesterol darah total yang diperoleh adalah 143,3 \pm 49,82 $\mathrm{mg} / \mathrm{dl}$. Hal ini memperlihatkan bahwa rerata kadar kolesterol darah total pasien hipertiroid mengalami penurunan dari nilai normal, yakni < $220 \mathrm{mg} / \mathrm{dl}$. Penurunan kadar kolesterol darah total pada pasien hipertiroid terjadi karena perubahan kadar hormon tiroid akan mempengaruhi metabolisme lipid (kolesterol) tubuh. Perubahan kadar hormon tiroid akan meningkatkan faktor yang menginduksi aktivitas HMG-CoA reduktase yang membuat biosintesis kolesterol endogen meningkat, akan meningkatkan aktivitas reseptor LDL jaringan, dan akan meningkatkan faktor yang menginduksi eksresi kolesterol di hati. Peningkatan aktivitas reseptor LDL jaringan akan meningkatkan perpindahan LDL ke jaringan dan secara tidak langsung juga akan meningkatkan perpindahan kolesterol ke jaringan karena fungsi LDL sebagai media transpor kolesterol ke jaringan juga meningkat. Peningkatan eksresi kolesterol juga akan meningkatkan perpindahan kolesterol dari jaringan ke hati. Kondisi peningkatan mobilisasi kolesterol ke jaringan dan mobilisasi dari jaringan ke hati ini, akan menyebabkan terjadinya penurunan kadar kolesterol darah total yang ada di sirkulasi. Mekanisme inilah yang diduga mendasari terjadinya penurunan kadar kolesterol darah total pasien hipertiroid dari nilai normal. Hubungan yang jelas antara peningkatan kadar FT4 dan penurunan kadar TSH serum sebagai indikator perubahan hormon tiroid dengan penurunan kadar kolesterol darah total pada pasien hipertiroid terlihat juga pada gambar 1. dan gambar 2. Pada gambar 1 . terlihat korelasi negatif antara kadar FT4 dengan kadar kolesterol darah total. Dimana semakin tinggi derajat peningkatan kadar FT4, maka semakin rendah kadar kolesterol darah total pasien hipertiroid. Sementara pada gambar 2 terlihat korelasi positif antara kadar TSH serum dengan kadar kolesterol darah total, dimana semakin tinggi derajat penurunan kadar TSH serum maka semakin rendah pula kadar kolesterol darah total pasien hipertiroid. Data penelitian para ahli di Nepal pada tahun 2010 juga menyebutkan bahwa rerata kadar kolesterol darah total pada pasien hipertiroid adalah 143,12 $\mathrm{mg} / \mathrm{dl}$, mengalami penurunan dari nilai normal. ${ }^{9,11,15,16,19}$

Rerata kadar HDL yang diperoleh dari penelitian adalah 42,06 $\pm 16,42 \mathrm{mg} / \mathrm{dl}$. Hal ini memperlihatkan bahwa rerata kadar $\mathrm{HDL}$ pasien hipertiroid mengalami penurunan dari nilai normal, yakni > $45 \mathrm{mg} / \mathrm{dl}$ ( $\left.{ }^{\lambda}\right)$ dan> $55 \mathrm{mg} / \mathrm{dl}(O)$. Penurunan kadar HDL pada pasien hipertiroid terjadi karena adanya perubahan kadar hormon tiroid yang akan mempengaruhi metabolisme lipid (HDL) tubuh. Perubahan kadar hormon tiroid akan meningkatkan aktivitas CEPT (Cholesteryl Ester Transfer Protein) yang berfungsi mengatur konversi HDL menjadi VLDL di hati (sehingga laju konversi HDL menjadi VLDL meningkat) dan meningkatkan eksresi kolesterol di hati. Peningkatan perpindahan HDL dari jaringan ke hati akan terjadi sebagai mekanisme kompensasi penurunan nilai HDL di hati karena adanya peningkatan kecepatan konversi HDL menjadi VLDL dan sebagai media transpor kolesterol ke hati yang meningkat karena terjadinya peningkatan eskresi kolesterol di hati. Kondisi peningkatan mobilisasi HDL dari jaringan ke hati ini, akan menyebabkan terjadinya penurunan kadar HDL yang ada di sirkulasi. Mekanisme inilah yang diduga mendasari terjadinya penurunan kadar HDL pasien hipertiroid dari nilai normal. Hubungan yang jelas antara peningkatan kadar FT4 dan penurunan kadar TSH serum sebagai indikator perubahan hormon tiroid dengan penurunan kadar HDL pada pasien hipertiroid terlihat juga pada gambar 3. dan gambar 4. Pada gambar 3. terlihat korelasi negatif antara kadar FT4 dengan kadar HDL. Dimana semakin tinggi derajat peningkatan kadar FT4, maka semakin rendah kadar HDL pasien hipertiroid. Sementara pada gambar 4. tidak terlihat korelasi antara kadar TSH serum dengan kadar HDL. Namun grafik yang menunjukkan arah korelasi positif berarti semakin rendah kadar TSH serum, maka semakin rendah pula kadar HDLpasien hipertiroid. ${ }^{9,11,15,16,19}$

Rerata kadar LDL yang diperoleh dari penelitian adalah $85,45 \pm 36,08 \mathrm{mg} / \mathrm{dl}$. Hal ini memperlihatkan bahwa rerata kadar LDL pasien hipertiroid mengalami penurunan dari nilai normal, yakni $<150 \mathrm{mg} / \mathrm{dl}$. Penurunan kadar LDL pada pasien hipertiroid terjadi karena adanya perubahan kadar hormon tiroid akan mempengaruhi metabolisme lipid (LDL) tubuh. Perubahan kadar hormon tiroid akan akan menginduksi SREBP-2 (Sterol Regulatory Element-Binding Protein-2) sebagai pengatur ekspresi gen reseptor LDL. Proses tersebut akan meningkatkan aktivitas reseptor LDL sel. Sehingga, terjadilah peningkatan pengikatan jumlah LDL di jaringan yang berakibat terjadinya peningkatan ambilan LDL dari sirkulasi ke jaringan. Peningkatan ambilan LDL dari sirkulasi ke jaringan tersebut akan menyebabkan terjadinya penurunan kadar LDL yang ada di sirkulasi. Mekanisme ini lah yang diduga mendasari terjadinya penurunan kadar LDL pasien hipertiroid dari nilai normal. Hubungan yang jelas antara peningkatan kadar FT4 dan penurunan kadar TSH serum sebagai indikator perubahan hormon tiroid dengan penurunan kadar LDL pada pasien hipertiroid terlihat juga pada gambar 5 dan gambar 6 . Pada gambar 5 terlihat korelasi negatif antara kadar FT4 dengan kadar LDL. Dimana semakin tinggi derajat peningkatan kadar FT4, maka semakin rendah kadar LDL pasien hipertiroid. Sementara pada gambar 6 terlihat korelasi positif antara kadarTSH serum dengan kadar LDL. Dimana semakin tinggi derajat penurunan kadar TSH serum, maka semakin rendah pula kadar LDL pasien hipertiroid. 9,11,15,16,19 $^{2}$

Rerata kadar trigliserida yang diperoleh adalah 77,19 $\pm 31,20 \mathrm{mg} / \mathrm{dl}$. Hal ini memperlihatkan bahwa rerata kadar trigliserida pasien hipertiroid mengalami penurunan dari nilai normal, yakni $<150$ $\mathrm{mg} / \mathrm{dl}$. Penurunan kadar trigliserida pada pasien hipertiroid terjadi karena adanya perubahan kadar hormon tiroid akan mempengaruhi metabolisme lipid (trigliserida) tubuh. Perubahan kadar hormon tiroid akan akan meningkatkan aktivitas LPL (Lipoprotein Lipase) di membran sel sebagai enzim katabolik trigliserida intravaskular. Proses tersebut akan meningkatkan proses hidrolisis trigliserida menjadi asam lemak dan gliserol, sehingga terjadilah peningkatan jumlah asam lemak yang melekat pada dinding endotel sel dan nantinya akan digunakan berdasarkan fungsi masing-masing sel. Hal ini berakibat terjadinya peningkatan mobilisasi trigliserida 
dari sirkulasi ke jaringan. Peningkatan mobilisasi trigliserida dari sirkulasi ke jaringan akan menyebabkan terjadinya penurunan kadar trigliserida yang ada di sirkulasi. Mekanisme inilah yang diduga mendasari terjadinya penurunan kadar trigliserida pasien hipertiroid dari nilai normal. Hubungan yang jelas antara peningkatan kadar FT4 dan penurunan kadar TSH serum sebagai indikator perubahan hormon tiroid dengan penurunan kadar trigliserida pada pasien hipertiroid terlihat juga pada gambar 7 . dan gambar 8. Pada gambar 7. tidak terlihat korelasi antara kadar FT4 dengan kadar trigliserida. Namun grafik yang menunjukkan arah korelasi negatif berarti semakin tinggi kadar FT4, maka semakin rendah kadar trigliserida pasien hipertiroid. Pada gambar 8 . tidak terlihat korelasi antara kadar TSH serum dengan kadar trigliserida. Namun grafik yang menunjukkan arah korelasi positif berarti semakin rendah kadar TSH serum, maka semakin rendah kadar trigliserida pasien hipertiroid. Data penelitian para ahli di Nepal pada tahun 2010 juga menyebutkan bahwa rerata kadar trigliserida pada pasien hipertiroid adalah $87,32 \mathrm{mg} / \mathrm{dl}$, mengalami penurunan dari nilai normal. $9,-11,15,16,19$

\section{KESIMPULAN}

1. Karakteristik pasien yakni dengan kelompok tertinggi di usia 35-44 tahun dan terbanyak berjenis kelamin perempuan.

2. Rerata kadar FT4 yang diperoleh mengalami peningkatan dari nilai normal dan rerata kadar TSH serum mengalami penurunan dari nilai normal.

3. Rerata kadar profil lipid darah yang diperoleh mengalami penurunan dari nilai normal.

4. Terdapat bukti korelasi negatif antara hubungan kadar FT4 dengan kadar kolesterol darah total, HDL, dan LDL.

5. Tidak terdapat bukti korelasi antara hubungan kadar FT4 dengan trigliserida.

6. Terdapat bukti korelasi positif antara hubungan kadar TSH serum dengan kadar kolesterol darah total dan LDL.

7. Tidak terdapat bukti korelasi antara hubungan kadar TSH serum dengan HDL dan trigliserida.

\section{UCAPAN TERIMA KASIH}

Ucapan terima kasih yang sedalam-dalamnya kepada Ibu DR. Eti Yerizel, MS dan Bapak dr. Rudy Afriant, Sp.PD atas bimbingan, arahan dan motivasi dalam penelitian ini.

\section{DAFTAR PUSTAKA}

1. Schteingert DE. Gangguan kelenjar tiroid, Dalam: Patofisiologi Jilid II. Edisi ke-6. Jakarta: EGC; 2006. hlm. 1225-30.

2. Suherman SK, Elysabeth. Hormon tiroid dan antitiroid. Dalam: Farmakologi dan Terapi. Edisi ke-5. Jakarta: Gaya Baru; 2007. hlm. 433-45.

3. Djokomoeljanto R. Kelenjar tiroid-hipotiroidhipertiroid, Dalam: Buku Ajar IImu Penyakit Dalam Jilid III. Edisi ke-5. Jakarta: Interna Publishing; 2009. hlm 1993-2008.

4. Murtedjo U, Tjakra WM, et. Sistem endokrin, Dalam: Buku Ajar IImu Bedah. Edisi ke-3. Jakarta: EGC; $2010 . \quad \mathrm{hlm}$. 806-7.
5. Regani F. Gambaran kadar malondialdehid (MDA) darah pada penderita hipertiroid (skripsi). Padang: FK Universitas Andalas; 2001.

6. American Association of Clinical Endocrinologist. The thyroid and cholesterol connection. (diunduh 8 Mei 2012) Tersedia dari: URL http://www.ajc.com

7. Gusni L. Gambaran kadar kolesterol darah pada penderita hipertioid (skripsi). Padang: FK Universitas Andalas; 2001.

8. Anwar R. Fungsi dan kelainan kelenjar tiroid Pertemuan Fertilitas Endokrinologi Reproduksi bagian Obstetri dan Ginekologi RSHS/FKUP, Bandung, 1 Juni 2005.

9. Guyton AC, Hall JE. Hormon metabolik tiroid, Dalam: Buku Ajar Fisiologi Kedokteran. Edisi ke11. Jakarta: EGC; 2008. hlm. 978-90.

10. Mittal $A$, et al. The clinical implications of thyroid hormones and its association with lipid profile: A comparative study from Western Nepal. Nepal Journal of Epidemiology. 2010. (diunduh 3 April 2013). Tersedia dari: URL: HYPERLINK http://www.nepjol.info/index.php/NJE/article/view/ 4102.

11. Rizos CV, Elisaf MS, Liberopoulus EN. Effects of thyroid dysfunction on lipid profile. Botham Open Cardiovaskular Medicine Journal. 2011 (diunduh 3 April 2013). Tersedia dari: URL: HYPERLINK http://www.ncbi.nlm.nih.gov/pmc/articles/PMC310 9527/

12. Ogunjimi A. Is low cholesterol dangerous. TJPRC'S Open Access International Journals. 2011 (diunduh 16 Februari 2013). Tersedia dari: URL: http://www.LIVESTRONG.com

13. Bond O, 2011. About low cholesterol. TJPRC'S Open Access International Journals. 2011 (diunduh 16 Februari 2013). Tersedia dari: URL : http://www.LIVESTRONG.com

14. Greenstein B, Diana W, 2007. Tiroid. Dalam: At Glance Sistem Endokrin. Edisi ke-2. Jakarta: Erlangga; hlm. 30-5.

15. Johson RR. Linear correlation, Dalam: Elementary Statistic. Edisi ke-3 . USA: Dux Bury Press;1980. hIm. 99-106.

16. Dahlan S. Statistik untuk kedokteran dan kesehatan. Edisi ke-5. Jakarta: Salemba Medika; 2008.

17. Ehrlich SD. Hyperthyroidism. Shore Health University of Maryland Medical System Article. 2010 (diunduh 21 Agustus 2013). Tersedia dari: URL: HYPERLINK http://health.shorehealth.org/ altmed/articles/hyperthyroidism-000088.htm

18. Cooper, David S. Hyperthyroidism. Medical Science Journal. 2003 (diunduh 6 Juni 2012). Tersedia dari: URL: HYPERLINK http://search.proquest.com/docview/199107001?a ccountid $=17242$

19. Botham KM, Peter AM, 2009. Sintesis-transporekskresi kolesterol, Dalam: terjemahan Biokimia Harper. Edisi ke-27. Jakarta: EGC; 2009. hlm. 239-49. 